Originals

\title{
Prognostic value of quantitative immune alterations in melanoma patients
}

\author{
R. Andrés, J. I. Mayordomo, D. Isla, P. Lasierraํㅗ, J. Godino, I. Marcos, A. Saenz, P. Escudero, J. Lambea, \\ E. Aguirre, E. Millastre, L. Larrad ${ }^{1}$, A. Tres
}

\section{Summary}

- Purpose: The immune response is altered in patients with neoplasms. Immunosuppression has important consequences in patients with melanoma. The aim of this study was to assess quantitative immune alterations in melanoma patients.

- Material and methods: We obtained a peripheral blood sample in EDTA from 86 melanoma patients (63 of them disease-free and 23 with distant disease). Total leukocytes and lymphocytes, B lymphocytes (CD19), types CD3, CD4, CD8 lymphocytes, and NK lymphocytes (CD56) were counted by determining the surface markers by flow cytometry, using a Coulter Epics Elite (Coulter Corp.). IgA, IgG, IgE and IgM were assayed by nephelometric methods employing a Hyland PDQ laser nephelometer.

- Results: We found significant differences between disease-free patients and those with active disease with regard to lymphocytes total count (median: 2251.57 vs. $1783.04 / \mathrm{mm}^{3}, \mathrm{p}=0.010$ ), NK lymphocytes (CD56) (149.54 vs. $\left.115.2 / \mathrm{mm}^{3}, \mathrm{p}=0.016\right)$, and IgA levels ( 241.59 vs. $\left.300.55 \mathrm{mg} / \mathrm{dl}, \mathrm{p}=0.044\right)$, when taken as continuous variables. When considering each parameter as a discontinuous variable, only changes in absolute lymphocyte count retained an statistical difference depending on the presence or absence of active disease, $73.9 \%$ of the patients with active metastatic disease having a lymphocyte count below 2000 cells $/ \mathrm{mm}^{3}$ versus only $36.5 \%$ of the disease-free patients ( 2 Pearson=9.476, $\mathrm{df}=1, \mathrm{p}=0.002$ ). The median survival for the 46 patients with absolute lymphocyte count above 2000 cells $/ \mathrm{mm}^{3}$ was 965 days $(\mathrm{DF}=65.03$, IC 95\%=792.721090.30) versus 441 days $(\mathrm{DF}=75.61$, IC 95\%=292.81-589.19) for the 40 patients with absolute lymphocyte count below 2000 cells/mm3 (log rank=4.54, $\mathrm{df}=1, \mathrm{p}=0.0331)$.

- Conclusions: There are significant differences in some lymphocyte populations and IgA levels between patients with metastases and disease-free patients. Melanoma patients with absolute lymphocyte levels above 2000 cells/mm3 have a longer survival than those with a lymphocyte count below 2000 cells $/ \mathrm{mm}^{3}$.

\section{Key words:}

Melanoma. Immune dysfunction. Total lymphocyte count. B lymphocyte (CD19). NK lymphocyte (CD56). IgA immunoglobulin.

Oncología, 2006; 29 (1):22-29

\footnotetext{
Division of Medical Oncology

${ }^{1}$ Division of Immunology

University Hospital Zaragoza, Spain.
} 


\section{Resumen}

- Introducción y objetivos: Los pacientes con cáncer presentan una alteración de la respuesta inmune. La inmunosupresión en melanoma, juega un papel importante. El objetivo de este estudio fue valorar las alteraciones cueantitativas de la inmunidad en pacienets con melanoma.

- Pacientes y métodos: Se obtuvieron muestras de sangre periférica en EDTA de 86 pacientes con melanoma (63 pacientes libres de enfermedad y 23 pacientes con metástasis a distancia). Los niveles de leucocitos totales, linfocitos totales, linfocitos CD3, linfocitos CD4, linfocitos CD8, linfocitos B (CD19) y linfocitos NK (CD56) fueron valorados mediante marcadores de superficie por citometría de flujo usando un Coulter Epics Elite (Coulter Corp). Los niveles de IgA, IgG, IgE e IgM fueron valorados por nefelometría usando un nefelómetro Hyland PDQ laser.

- Resultados: Hubo diferencias significativas entre pacienets metastásicos y pacientes libres de enfermedad en los niveles de linfocitos totales (mediana: 2251.57 vs $1783.04 / \mathrm{mm}^{3}, \mathrm{p}=.001$ ), linfocitos B (CD19) (216.1 vs $\left.108.36 / \mathrm{mm}^{3}, \mathrm{p}=.010\right)$, linfocitos NK (CD56) (149.54 vs $\left.115.2 / \mathrm{mm}^{3}, \mathrm{p}=.016\right)$ y niveles de IgA (241.59 vs $300.55 \mathrm{mg} \mathrm{dL}, \mathrm{p}=.044$ ) al considerarlas como variables continuas. Al considerar cada parámetro de estudio como una variable cualitativa, sólo se observaron diferencias significativas en los niveles totales de linfocitos, existiendo un $73.9 \%$ d elos pacientes con enfermedad a distancia niveles d elinfocitos por debajo de 2000 células $/ \mathrm{mm}^{3}$ frente a un $36.5 \%$ de pacienets libres de enfermedad $\left(\chi^{2}\right.$ Pearson $\left.=9.476, \mathrm{df}=1, \mathrm{p}=.002\right)$. La mediana de supervivencia para 46 pacientes con niveles totales de linfocitos por encima de 2000 células $/ \mathrm{mm}^{3}$ fue de 965 días $(\mathrm{DF}=65.03$, IC $95 \%=792.72-1090.30)$ frente a 441 días $(\mathrm{DF}=75.61$, IC $95 \%=$ 292.81 - 589.19) para 40 pacientes con niveles totales de linfocitos 2000 células / mm3 (log rank = 4.54, df=1, $\mathrm{p}=.0331)$.

- Conclusiones: Existen diferencias significativas en los niveles de algunas subpoblaciones linfocitarias y en los niveles de IgA entre pacienets metastásicos y pacienets libres de enfermedad. Los pacientes con melanoma con niveles de linfocitos totales por encima de 2000 cells/mm3 tiene una mayor supervivencia que aquellos con niveles por debajo de 2000 cells $/ \mathrm{mm}^{3}$.

Palabras clave: Melanoma. Disfunción inmune. Linfocitos totales. Linfocito B (CD19). Linfocito NK (CD56). Inmunoglobulina IgA.

\section{Introduction}

Four decades of research leave little doubt that the immune response to tumor antigens and probably to other antigens is altered in patients with cancer. However, this diminished immune response in cancer patients is clearly different from the generalized immunosuppression seen in patients receiving high doses of corticosteroids or chemotherapy. In addition, it is apparent that immune dysfunction is antigen-specific in the initial stages of disease and becomes more generalized with tumor progression $^{1}$. Several reports show quantitative alterations of the immune system in patients with advanced neoplasm. Finco el al studied patients with esophageal cancer and found immunological alterations consisting of reduced cytotoxic T lymphocyte (CD8) counts and inversion of the CD4/CD8 ratio associated to malnutrition of these patients. They concluded that the acquired immunodeficiency present in patients with esophageal cancer is due to severe malnutrition and not to the neoplasm itself ${ }^{2}$.

The importance of the immune system in metastatic melanoma, as evidenced by lymphoid infiltration into tumour and surrounding tissues and reported spontaneous remissions, has been known for long $^{3-8}$. A number of studies aimed to identifying molecular alterations in the antitumor immune response in patients with melanoma have been performed in the last years ${ }^{9,10}$. Melanoma antigens recog- 
nized by $\mathrm{T}$ lymphocytes habve also been identified ${ }^{11}$. This may well lead to better anticancer immunotherapies in the near future cáncer. Quantitative alterations in the immune system of melanoma patients have not been studied in depth. The study by Jovic et al shows lower number and lower proliferative activity of natural $\mathrm{j} i$ killer cells from melanoma patients when compared to controls ${ }^{12}$. As in other cancers, immune alteratios in melanoma patients are more intense in those with disseminated disease. In the present study we looked for quantitative immune alterations in patients with disseminated melanoma when compared to those who were disease-free. We analysed the percentage and absolute number of lymphocyte populations and subpopulations, and levels of immunoglobulines in these patients. We also evaluated the prognostic value of the immune alterations found.

\section{Material and methods}

\section{Patients}

From January 1999 to June 2001, 86 peripheral blood samples were obtained from 86 patients with histologically proven melanoma attending the Melanoma Clinic of the University Hospital of Zaragoza.

In all patients with non-metastatic melanoma, blood samples were taken after full staging, surgery and informed consent. Clinical staging was performed according to the 2001 criteria of the Union Internationale Contre le Cancer (UICC). First of all, a careful pathology review of the primary melanoma including Breslow and Clark level and presence of ulceration was performed. Following clinical examination, complete blood cell counts, serum biochemistry, chest X-rays and ultrasonography of the abdomen, all patients without distant metastases or palpable regional lymph nodes underwent sentinel lymph node biopsy (plus regional lymphadenectomy if tumour cells were seen in the sentinel node with hematoxilin-eosin or by immunohistochemistry). CT and MRI were used when clinically indicated. Patients undergoing chemotherapy, immunotherapy or on corticosteroids and those with active infection were excluded from this study. There were 63 patients with non-metastatic melanoma and no evidence disease, while 23 patients had distant disease.
Eighty-three patients had cutaneous melanoma, one had nasal mucosal melanoma and two had ocular melanoma. There were 45 men (52\%) and 41 women (48\%). Median age was 52 (range: 4-78). In the group with non-metastatic melanoma, there were 27 men and 36 women with a median age of 52 (range: 4-78). As for the group of patients with distant disease, there were 14 men and 9 women with a median age of 50 (range: 20-74). No patient was lost for follow-up. Median follow-up time was 329 days or to death.

\section{Analysis of surface markers by flow cytometry}

A venous blood sample was collected in EDTA and analysed for surface markers within 4 hours. WBC counts were determined using an automated cell counter (Coulter MD II, Coulter Corp.,Hialeah, FL, USA). Leukocytes were analyzed for surface markers by direct addition of labelled monoclonal antibodies (Mabs) to 50-100 uL blood containing < $1 \times 10^{6} \mathrm{WBC}$. After $30 \mathrm{~min}$ incubation at $+4^{\circ} \mathrm{C}$ with Mabs, RBC were lysed and fixed by coulter Q-prep (Coulter Corp.) and analysis by multiparameter flow cytometry using a Coulter Epics Elite (Coulter Corp.) was performed. The total leukocyte population was analysed, with gating for lymphocytes, monocytes and granulocytes according to their forward scatter (FS) and side scatter (SCC) properties and reactivity with anti-CD14 and anti-CD45. The total lymphocytes count was determined by multiplying the percentage of lymphocytes (CD14 $/ \mathrm{CD} 45^{++}$) by the total WBC count. For lymphocyte subsets the following Mabs labelled with FITC or phycoerythrin (RD) were used; anti-CD3 (clone UCHT1), anti-CD4 (T4), anti-CD8 (T8), anti-CD2 (T11), anti-CD19 (B4), anti-CD56 (NKH1), antiCD45RA (2H4), anti-HLA-DR (13) all from Coulter Corp. Anti-CD45RO (UCHL1) were purchased from DAKO (Copenhagen, Denmark) and antiCD16 (Leu 11c) from Becton Dickinson.

The absolute number of cells in any given lymphocyte population was calculated by multiplying the percentage of positive cells in the lymphocyte gate by the absolute number of lymphocytes.

\section{Assay of immunoglobulins}

IgA, IgG, IgE and IgM levels were assayed by nephelometric methods using a Hyland PDQ laser 
TABLE I

Significant differences between melanoma patients who were disease-free versus those with active disease in peripheral peripheral blood lymphocyte subpopulations and immunoglobulin levels

\begin{tabular}{|c|c|c|c|c|}
\hline Parameter & Units & $\begin{array}{c}\text { Median value (range) } \\
\text { disease-free patients }\end{array}$ & $\begin{array}{c}\text { Median value (range) } \\
\text { Patients with active disease }\end{array}$ & 2 -sided $p$ \\
\hline B lymphocytes (CD19) & cells $/ \mathrm{mm}^{3}$ & $216.10(15.60-975)$ & $108.36(4-275)$ & .001 \\
\hline Total lymphocyte & cells $/ \mathrm{mm}^{3}$ & $2251.57(760-4130)$ & $1783.04(400-3180)$ & .010 \\
\hline NK lymphocyte (CD56) & cells $/ \mathrm{mm}^{3}$ & $149.54(45.6-546)$ & $115.20(28-254)$ & .016 \\
\hline Immunoglobulin A & $\mathrm{mg} / \mathrm{dl}$ & $241.59(66.5-718)$ & $300.55(91.7-689)$ & .044 \\
\hline CD4 lymphocytes & cells $/ \mathrm{mm}^{3}$ & $1002.96(251.46-2180)$ & $823.98(80-1717.20)$ & .070 \\
\hline CD3 Lymphocytes & cells $/ \mathrm{mm}^{3}$ & $1447(486.4-3469.2)$ & $1339.6(212-2108)$ & .081 \\
\hline Immunoglobulin E & $\mathrm{UI} / \mathrm{ml}$ & $46.57(2.9-258)$ & $114.37(2.2-665)$ & .193 \\
\hline CD4 / CD8 ratio & $\mathrm{Mg} / \mathrm{dl}$ & $2.10(0.58-6.33)$ & $2.02(0.65-4.91)$ & .285 \\
\hline CD8 lymphocytes & cells $/ \mathrm{mm}^{3}$ & $982.27(185.6-27423.9)$ & $450.66(124-780)$ & .322 \\
\hline Absolute leukocyte count & cells $/ \mathrm{mm}^{3}$ & $7304.92(2610-33900)$ & $8847.82(2200-22800)$ & .382 \\
\hline Immunoglobulin $\mathrm{G}$ & $\mathrm{mg} / \mathrm{dl}$ & $1003.36(529-1550)$ & $970(554-1550)$ & .516 \\
\hline Immunoglobulin $\mathrm{M}$ & $\mathrm{mg} / \mathrm{dl}$ & $119.57(29.1-310)$ & $138.28(39.5-424)$ & .725 \\
\hline
\end{tabular}

nephelometer. In brief, standards over the range from 125 to $8,000 \mathrm{ng} / \mathrm{ml}$ were prepared by dilution of standards provided by Hyland for routine estimation of $\operatorname{IgG}$, IgM and IgA. Antisera to IgM and IgA were supplied by Dako and used at a final dilution of 1:100 in nephelometer buffer. The IgG antiserum was from Silenus Laboratories (Melbourne, Australia) and used at a dilution of 1:100. All antisera showed no reactivity with fetal calf serum and were shown to be class-specific by assaying against purified $\mathrm{IgG}, \operatorname{IgM}$ and $\operatorname{IgA}$. Supernants from triplicate cultures were centrifuged twice at 2,000 g for 10 min and 100-ml samples were used for assay of $\operatorname{IgM}, \operatorname{IgA}$, and IgG and sample blanks. One hundred $\mathrm{ml}$ of RPMI-1640 containing 10\% FBS were added to the standards to make the assay fluid similar to that of the samples from tissue cultures. Independent standard serum samples were used in each assay as a measure of reproducibility of the immunoglobulin concentration.

\section{Statistical analysis}

Statistical analysis was performed using the U Mann Whitney test for two independent samples. A value of $P<0.05$ was considered to be significant. Plotting of survival curves was carried out according to Kaplan-Meier. Survival time was measured from date of blood sampling to death or last followup.

\section{Results}

In patients with malignant melanoma, mean of peripheral blood lymphocyte subpopulations and immunoglobulin levels were related to clinical situation. We found significant differences between patients who were disease-free and those with active disease in B lymphocyte count (CD19), total lymphocyte count (2-sided, $\mathrm{p}=.001)$, NK Lymphocyte count (CD56) and IgA levels when taken as continuous variables (Table I). The median value of B lymphocyte count in disease-free patients was 216.10 cells $/ \mathrm{mm}^{3}$ versus 108.36 in metastatic patients (2-sided, $\mathrm{p}=.001$ ). The median value of total lymphocyte count in disease-free patients was 2251.57 cells $/ \mathrm{mm}^{3}$ versus 1783.04 cells $/ \mathrm{mm}^{3}$ in metastatic patients (2-sided, $\mathrm{p}=.01)$. The median value of NK lymphocyte count in disease-free patients was 149.54 cells $/ \mathrm{mm}^{3}$ versus 115.20 cells $/ \mathrm{mm}^{3}$ in metastatic patients (2-sided, $\mathrm{p}=.016)$. The median value of IgA levels in disease-free patients was $241.59 \mathrm{mg} / \mathrm{dl}$ versus $300.55 \mathrm{mg} / \mathrm{dl}$ in metastatic patients (2-sided, $\mathrm{p}=.044)$. For the rest of parameters there were no statistically significant differences. There was a non-significant trend (2-sided, $\mathrm{p}=.070$ ) in CD4 lymphocyte count.

When taking each parameter as a discontinuous variable only differences in absolute lymphocyte count retained statistical difference depending on the presence or absence of active disease, with 
TABLE II

Total lymphocyte counts are significantly different between melanoma patients who were disease-free (non-metastatic melanoma) versus those with active disease (metastatic melanoma)

\begin{tabular}{|lcc|}
\hline & $\begin{array}{c}\text { Non metastatic } \\
\text { melanoma }\end{array}$ & $\begin{array}{l}\text { Metastatic } \\
\text { melanoma }\end{array}$ \\
\hline $\begin{array}{l}\text { Lymphocyte count } \\
<\text { or }=2000 / \mathrm{mm}^{3} \\
\text { Lymphocyte count } \\
>2000 / \mathrm{mm}^{3}\end{array}$ & $23(36.5 \%)$ & $17(73.9 \%)$ \\
\hline
\end{tabular}

$\left(\chi^{2}\right.$ Pearson $\left.=9.476, \mathrm{df}=1, \mathrm{p}=.002\right)$.

$73.9 \%$ of patients with active metastatic disease having lymphocyte count below 2000 cells $/ \mathrm{mm}^{3}$ versus only $36.5 \%$ of patients who were disease-free $\left(\mathrm{c}^{2}\right.$ Pearson $\left.=9.476, \mathrm{df}=1, \mathrm{p}=.002\right)($ Table II $)$. Median survival for forty-six patients with absolute lymphocyte count above 2000 cells $/ \mathrm{mm}^{3}$ was 965 days $(\mathrm{DF}=65.03$, IC 95\%= $792.72-1090.30)$ versus 441 days $(\mathrm{DF}=75.61$, IC $95 \%=292.81-589.19)$ for forty patients with absolute lymphocyte count below 2000 cells $/ \mathrm{mm}^{3}(\log$ rank $=4.54, \mathrm{df}=1, \mathrm{p}=$ .0331) (Figure 1). In the 63 patients who were disease-free, median survival of those with total lymphocytes $<2000 / \mathrm{mm}^{3}$ was 965 days, while the median was not reached in those with $>2000 / \mathrm{mm}^{3}$, without significant differences $(\log \operatorname{rank}=.00, \mathrm{df}=1$,

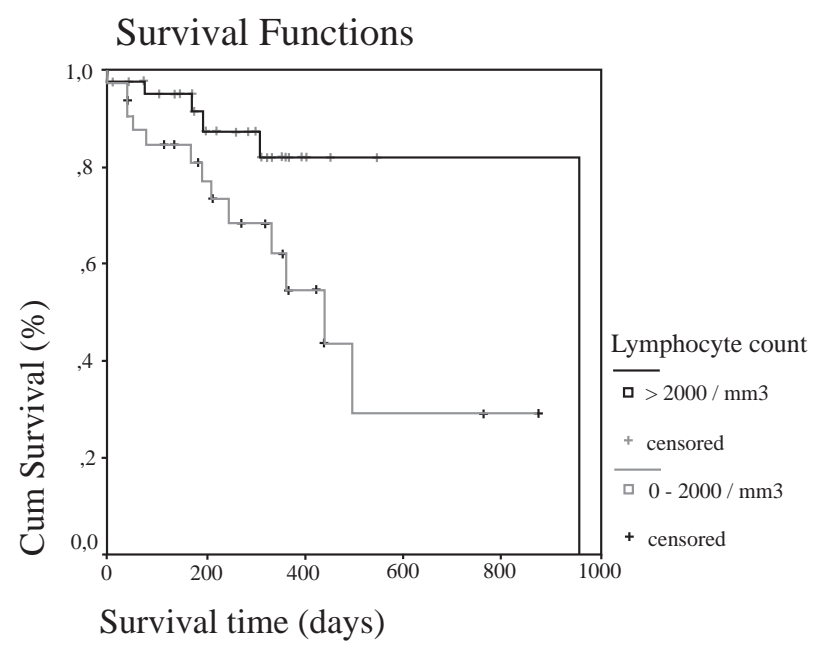

Figure 1. Survival curve according to lymphocyte count in patients with melanoma. $\mathrm{p}=$.9486). Within the 23 patients with disseminated disease, no statistically significant differences in median survival were found either between patients with lymphocyte counts $>$ or $<2000 / \mathrm{mm}^{3}$ (197 days for patients with $<2000$ versus 202 days for those with $>2000 / \mathrm{mm}^{3}(\log$ rank $=.00, \mathrm{df}=1, \mathrm{p}=.9486)$.

\section{Discusion}

Few reports have assessed quantitative immune alterations in patients with melanoma. In the present study, significant differences in total lymphocyte count, B lymphocyte count, NK lymphocyte count and immunoglobulin A level were found between melanoma patients who were disease-free and those with active metastases. Total lymphocyte counts are significantly higher in patients who are disease-free. In addition, patients with total lymphocyte counts above 2000 cells $/ \mathrm{mm}^{3}$ have significantly longer survival. As for lymphocyte subpopulations both B lymphocyte (CD19) and NK lymphocyte (CD56) counts are also significantly higher in patients who are disease-free. On the contrary, immunoglobulin A levels are significantly higher in patients with active disease.

These results are consistent with those found in prior reports. Jovic et al. assessed cytotoxic activity, CD69 expression and relative NK lymphocyte count in peripheral blood from 34 patients with metastatic melanoma and 36 control individuals. T lymphocyte counts and proliferative activity were also assessed in both groups. Results show that NK lymphocyte percentage is lower in patients with metastatic melanoma versus control individuals (median $=16.32$ versus $20.61 \%, p<.05)$. This is associated to enhanced cell activity and decreased CD69 expression in patients with metastatic melanoma $(\mathrm{p}<.05)$. Proliferative activity of $\mathrm{T}$ lymphocytes is also lower in patients with metastatic melanoma $(\mathrm{p}<$ .01 ), and relative circulating $\mathrm{T}$ lymphocyte, helper T lymphocyte (CD4) and cytotoxic T lymphocyte (CD8) counts were also significantly lower ( $\mathrm{p}<$ $.05)^{12}$. Hayne et al performed flow cytometric analysis of circulanting lymphocyte subpopulations in 226 patients with choroidal melanoma and 49 control individuals. They found no significant differences overall. When dividing the population of patients with choroidal melanoma according to the cli- 
nical features of the tumor, a significant reduction of NK cells was found in patients with cilliary body involvement (194+/-101 versus $260+/-178$ per $\mathrm{mm} 3, \mathrm{p}=.01)$ and a significant increase in $\mathrm{T}$ lymphocyte activity was found in patients with extrascleral involvement $(9.84+/-7.41$ versus $6.25+/-4.3$ per $\mathrm{mm} 3, \mathrm{p}=.02)^{13}$. In the report by Wermeister et al, resection of localized-stage melanoma is followed by reduction of suppressor cell activity leading to increased immunoglobulin production ${ }^{14}$.

Several reports show quantitative alterations of the immune system in patients with advanced neoplasm $^{2}$. In most published reports, patients with advanced neoplasm have alterations in routine blood tests, such as hemoglobin levels, so we have to be careful when drawing conclusions as to whether the neoplasm and not to the deterioration in physical condintion is responsible of the immune abnormalities seen ${ }^{15}$.

In the present report, patients with lymphocyte counts $>2000 / \mathrm{mm}^{3}$ had significantly longer survival than those with $<2000$ células/mm3 (965 days versus 441 days). A multivariate analysis is needed to check whether the prognostic value of lymphocyte count is independent of stage and other parameters associated to disseminated disease in patients with melanoma. Anyway, the present findings and those reported previously by other investigators guide the development of novel therapies for melanoma. Knowing that the immune system plays an important role in the development and progression of melanoma ${ }^{1,3-5,9,10}$, immune-based therapies have been tested in patients with melanoma, both in the adjuvant setting ${ }^{16}$ and in disseminated disease. This has led to attempts to modulate the immunological environment of tumours, usually by the use of cytokines, especially interferon-alpha and interleukin-2, given directly or by gene therapy. This has improved the outcome in other tumours ${ }^{17}$. For theoretical reasons of synergy and in an attempt to improve the efficacy of existing regimens, these agents have been combined with cytotoxic agents. It is unclear whether such combinations offer a therapeutic advance over simpler and less toxic treatments ${ }^{18-29}$.

A multivariate análisis in patients with disseminated melanoma comparing dacarbacine monochemotherapy versus dacarbacine plus immunotherapy showed that the combination of DTIC and interferon-alpha appears more active than standard single- agent DTIC in metastatic melanoma ${ }^{30}$. Further randomized clinical trials employing a DTIC plus interferon arm are necessary to confirm these results.

Quantitative immune alterations in melanoma patients can also be useful to monitor response to therapy as shown in studies by S. Rosenberg. In a series of patients with disseminated renal cancer or melanoma treated with interleukin-2, responders had a higher maximum lymphocyte count immediately after therapy compared with nonresponders. The development of vitiligo after therapy was associated with response ${ }^{31}$.

Molecular alterations in the immune system of cancer patients have also been investigated. These alterations are found even in early-stage cancer and are involved in disease progression. The relevance of such alterations is exemplified in the report by Mizoguchi et al: They identified an acquired defect in the $\mathrm{Z}$ chain of the $\mathrm{T}$ cell antigenic receptor (TCR) in patients with disseminated cancer ${ }^{9}$. Correa et al have characterized the sequence of molecular events leading to loss of TCR zeta chain in lymphocytes from cancer-bearing hosts ${ }^{10}$. Alterations in NF Kap$\mathrm{paB}$ family proteins, specifically the failure of p65 translocation to the nucleus, are the earliest event identified. These qualitative alteration secondary to cancer-induced immunosupression may well result in the quantitative immune alterations found in the present report in patients with disseminated melanoma.

It is important to learn more about immune alterations induced by malignant tumors in order to design better strategies of immunotherapy.
Correspondence:

Dra. R. Andrés

Division of Medical Oncology Hospital Clínico Universitario

Av. San Juan Bosco, 15

E-50009 Zaragoza

Spain

E-mail: andresraquel@ hotmail.com 


\section{Bibliography}

1. Staveley-O Carroll K, Sotomayor E, Montgomery J, Borrello I, Hwang L, Fein S, Pardoll D, Levitsky H. Induction of antigen-specific T cell anergy: An early event in the course of tumor progression. Proc Natl Acad Sci USA. 1998 Feb 3;95(3) 1178-83.

2. Finco C, Rossi M, Pittoni G et al. Relazione tra stato nutrizionale ed immunologico nel paziente con cancro esofageo. Minerva Med 1991;82:529-37.

3. Nordlund JJ, Kirwood JM, Forget BM, Milton G, Albert DM, Lerner AB. Vitiligo in patients with melanoma. A good prognostic sign. J. Am. Acad. Dermatol 1983, 9:689.

4. Bystryn J-C, Rigel D, Friedman RJ, Kopf A. Prognostic significance of hypopigmentation in malignant melanoma. Arch. Dermatol. 1987, 123:1053.

5. Clark WH, Elder DE, Guerry D, Braitman LE, Trock BJ, Schultz D, Synnestvedt M, Halpern AC. Model predicting survival in stage I melanoma based on tumor progression. J. Nat. Cancer Inst. 1989,81:1893.

6. Taylor A and Gore M. Treatment of Cancer 1995;Chapman and Hall Medical, 37:Third Edition, London, 7637Price P and Sikora K.

7. Cascinelli N, Clemente C and Belli F. Oxford Textbook of Oncology 1995;Oxford University Press, Oxford, 9028Peckham M, Pinedo HM, Veronesi U.

8. Balch CM, Houghton AN, Peters LJ. Cancer: Principles and Practice of Oncology 1993;J.B. Lippincott Co, Fourth Edition, Philadelphia, 1612-61Devita VT Jr., Hellman S, Rosenberg SA.

9. Mizoguchi H, O’Shea JJ, Longo DL et al. Alterations insignal transduction molecules in $\mathrm{T}$ lymphocytes from tumor-bearing mice. Science 1992;258:1795-7.

10. Correa MR, Ochoa AC, Ghosh P, Mizoguchi H, Harvey L, Longo DL. Sequential development of structural and functional alterations in T cells from tumo-bearing mice. J Immunol 1997 ;158(11):5292-6.

11. Rosenberg, S. A.; Yang, J. C.; White, D. E.; Steinberg, S. M. Durability of Complete Responses in Patients With Metastatic Cancer Treated With High-Dose Interleukin-2. Identification of the Antigens Mediating Response. J Urol 1999; 162(2): 637.

12. Jovic V, Konjevic G, Radulovic S et al. Impaired perforindependent NK cell cytotoxicity and proliferative activity of peripheral blood $\mathrm{T}$ cells is associated with metastatic melanoma. Tumori 2001; 87(5): 324-9.

13. Haynie GD, Shen TT, Graugodas ES et al. Flow cytometry analysis of peripheral blood lymphocytes in patients with choroidal melanoma. Am J Ophthalmol 1997; 124(3):357-61.

14. Werkmeister J, McCarthy W, Hersey P. Suppresor cell activity in melanoma patients. Relation to tumor growth and inmunoglobulin levels in vivo. Int J Cancer 1981: 28,1-9.

15. Stanley KE. Prognostic factors for survival in patients with inoperable lung cancer. J Natl Cancer Inst. 1980 Jul;65(1):25-32.
16. Kirkwood JM, Strawderman MH, Ernstoff MS, Smith TJ. Interferon alfa-2b adjuvant therapy of high risk resected cutaneous melanoma: the eastern cooperative oncology group trial EST 1684. J Clin Oncol, Vol 14, No 1 (Jan), 1996: pp 7-17.

17. Atzpodien J, Kirchner H, Franzke A, Wandert T, Probst M, Buer J, Duensing S, Ganser A. Results of a randomised clinical trial comparing SC interleukin-2, SC alpha-2a-interferon, and IV bolus 5-fluorouracil against oral tamoxifen in progressive metastati c renal cell carcinoma patients. Proc. Am. Assoc. Clin. Oncol. 1997;16:326.

18. Rosenberg SA, Lotze MT, Yang JC, et al: Combination therapy with interleukin-2 and alpha-interferon for the treatment of patients with advanced cancer. J Clin Oncol 1989;7:1863-1874.

19. Kruit WHJ, Goey SH, Monson JRT, et al: Clinical experience with the combined use of recombinant interleukin-2 and interferon alfa- $2 \mathrm{a}$ in metastatic melanoma. $\mathrm{Br} \mathrm{J}$ Haematol 1991;79(suppl 1):84-86.

20. SS Legha, S Ring, O Eton, A Bedikian, AC Buzaid, C Plager and N Papadopoulos. Development of a biochemotherapy regimen with concurrent administration of cisplatin, vinblastine, dacarbazine, interferon alfa, and interleukin-2 for patients with metastatic melanoma. J Clin Oncol 1998;16:1752-59.

21. Richards JM, Gale D, Mehta N, Lestingi T. Combination of Chemotherapy With Interleukin-2 and Interferon Alfa for the Treatment of Metastatic Melanoma. J Clin Oncol 1999;17(2):651-64.

22. E Filipovich, JI Mayordomo, JA Meana, M Valladares, J Florian, JJ Bretón, R Blanco, D Isla, C Santander, R Andrés, B Massuti, A Tres. Bioquimioterapia ambulatoria con cisplatino, dacarbacina, interleucina-2 e interferon-alfa en pacientes con melanoma avanzado. Estudio multicéntrico en 44 pacientes. Rev Oncol 2003;5(2):79-87.

23. Khayat D, Borel C, Tourani JM, et al: Sequential chemoimmunotherapy with cisplatin, interleukin-2 and interferon-alfa-2a for metastatic melanoma. J Clin Oncol 1993;11:2173-2180.

24. Atzpodien J, Lopez Hanninen E, Kirchner H, et al: Chemoimmunotherapy of advanced malignant melanoma: Sequential administration of subcutaneous interleukin-2 and interferon-alpha after intravenous dacarbazine and carboplatin or intravenous dacarbazine, cisplatin, carmustine and tamoxifen. Eur J Cancer 1995;31A:876-881.

25. Keilholz U, Goey SH, Punt CJA, et al: A randomized trial of IFN alfa/IL-2 with or without CDDP in advanced melanoma: An EORTC Melanoma Cooperative Group trial. Proc Am Soc Clin Oncol 1996;15:436 (abstr 1353).

26. Rosenberg SA, Yang JC, Schwartzentruber DJ, Hwu P, Marincola FM, Topalian SL, Seipp CA, Einhorn JH, White DE, Steinberg SM. Prospective Randomized Trial of the Treatment of Patients With Metastatic Melanoma Using Chemotherapy With Cisplatin, Dacarbazine, and Tamoxifen Alone or in Combination With Interleukin-2 and Interferon Alfa-2b. J Clin Oncol 1999;17(3): 968. 
27. Ridolfi R, Chiarion-Sileni V, Guida M, Romanini A, Labianca R, Freschi A, Re GL, Nortilli R, Brugnara S, Vitali P, Nanni O. Cisplatin, Dacarbazine, with or without subcutaneous interleukin-2 and interferon alpha2b in advanced melanoma outpatients: results from an italian multicenter phase III randomized clinical trial. J Clin Oncol 2002;20(6):1600-7.

28. Eton O, Legha SS, Bedikian AY, Lee JJ, Buzaid AC, Hodges C, Ring SE, Papadopoulos NE, Plager C, East MJ, Zhan F, Benjamin RS. Sequential Biochemotherapy Versus Chemotherapy for Metastatic Melanoma: Results From a Phase III Randomized Trial. J Clin Oncol 2002; 20(8): 2045-2052.

29. Atkins MB, LeeS, Flaherty LE. A prospective randomized phase III trial of concurrent biochemotherapy wiht cisplatin, vinblastine, dacarbazine, IL2 and interferon versus CVD alone in patients with metastatic malignant melanoma: an ECOG-coordinated intergroup trial. Proceed ASCO. 2003;22:708 (A2847).

30. Huncharek M, Caubet JF, McGarry R. Single-agent DTIC versus combination chemotherapy with or without immunotherapy in metastatic melanoma: a meta-analysis of 3273 patients from 20 randomized trials. Melanoma Research 2001;11(1):75-81.

31. Phan GQ, Attia P, Steinberg SM, White DE, Rosenberg SA. Factors Associated With Response to High-Dose Interleukin-2 in Patients With Metastatic Melanoma. J Clin Oncology, 2001; 19(15): 3477-3482. 